\title{
Substrate and depth preferences of macroinvertebrates along a transect in a Pyrenean high mountain lake (Lake Redó, NE Spain)
}

\author{
M. Rieradevall, N. Bonada and N. Prat \\ Departament d'Ecologia, Universitat de Barcelona, Diagonal 645, 08028 Barcelona. Spain.
}

\begin{abstract}
We studied the macrozoobenthos along a transect in Lake Redó (Pyrenees), within the framework of the European programme MOLAR (Mountain Lake Research). Samples were taken at 2-metre intervals at depths from 4 to 20 metres by SCUBA divers. Two kinds of samples were taken, individual stones (three replicates) and cores (three replicates) from the soft sediment areas. In the deeper areas, samples were taken with an Ekman grab. All the samples were taken on the same date (15 July 1997). Using the Mantel autocorrelogram analysis two discontinuities were found in the stony bottom community. The first was at 4 $\mathrm{m}$, and distinguishes the littoral from the sublittoral community, and the second was at $14 \mathrm{~m}$, coincident with the lower part of the thermocline in summer. The layer is characterized by the fact that it receives less than $10 \%$ of surface incident light, by greater accumulation of detritus on stones and by the disappearance of macroscopic algae covering stones down to this depth. Several species preferred soft bottom areas (Oligochaeta, Micropsectra radialis and Pseudodiamesa nivosa, among the chironomids), while others were more abundant on the stones (Radix peregra, Plectrocnemia laetabilis, Psectrocladius octomaculatus). These results should be useful in aiding interpretation of data from subfossil records from cores taken in the lake.
\end{abstract}

Keywords: mountain lakes, macroinvertebrates, chironomids, depth distribution, substrate preferences

\section{RESUMEN}

Se estudia la composición y estructura de la comunidad de macroinvertebrados a lo largo de un transecto en profundidad en el lago Redó (Pirineos). Este estudio se enmarca dentro del proyecto de ámbito europeo MOLAR (Mountain Lake Research). Un equipo de buceadores muestreó dos tipos de substrato, piedras y fondos blandos, cada $2 \mathrm{~m}$ desde los 2 a los $20 \mathrm{~m}$ de profundidad. En la parte más profunda del lago las muestras se tomaron con draga Ekman (tres réplicas). Todas las muestras se tomaron el mismo día, el 15 de Julio de 1997. Los resultados, mediante un análisis de autocorrelación de Mantel, muestran que no existe un gradiente continuo en la sustitución de unas especies por otras en la comunidad sobre substrato rocoso, sino que se distinguen dos discontinuidades claras, una a los 4 metros y otra a los 14 metros. La primera separa las especies propias de la zona litoral respecto a las de la zona sublitoral, mientras que la segunda coincide con la parte inferior de la termoclina, una zona siempre mas fría, con menos luz y con mayor acumulación de material fino sobre los sustratos duros a la vez que desaparece la cobertura algal que cubría las piedras hasta esta profundidad. Respecto al sustrato existen especies que claramente prefieren el sustrato blando (oligoquetos, o los quironómidos Micropsectra radialis y Pseudodiamesa nivosa), mientras que otras eran más abundantes o exclusivas de los sustratos duros (Radix peregra, Plectrocnemia laetabilis, Psectrocladius octomaculatus). Estos resultados seran muy útiles para la interpretación de los datos paleolimnológicos de los cores que actualmente se están estudiando en el lago.

Palabras clave: lagos de montaña, macroinvertebrados, quironómidos, distribución en profundidad, preferencia de sustrato. 


\section{INTRODUCTION}

The variation in the diversity and density of macrozoobenthos with water depth has been studied in many lakes and a fall in both parameters has been frequently observed (Brinkhurst, 1974), even in high mountain lakes (Uutala, 1981). Jónasson (1978) summarized the factors involved as follows: physical factors including exposure to wind and currents, chemical factors (mainly related to the quantity of dissolved oxygen), physiological adaptations, food quality and quantity, the type of substrate and intra and/or interspecific competition. The combination of these factors in each lake explains the differences in the bathymetric distribution of species, although it hinders comparison between lakes because not all factors are modified in the same way in all lakes. Moreover, most of the studies describing bathymetric distributions refer to soft bottoms, because samples are more easily comparable, while the collection of invertebrate samples from stony bottoms is more complex. In order to obtain replicate and representative samples of macrozoobenthos, the use of SCUBA divers provides the best option, but this method has limitations regarding the maximum depth at which samples can be taken. In addition, in remote high mountain lakes, the sampling difficulties encountered by divers increase, due to their remoteness and low temperature of the water. Thus, few studies have been performed using this method in cold lakes (Särkkä, 1983).

The aim of this study was to gather autoecological information about the macroinvertebrate benthic organisms of a high mountain lake (Lake Redó in the Pyrenées, NE Spain), as an aid to palaeolimnological interpretations of subfossil records obtained from lake sediment cores. The main questions raised in this study are related to the depth or substrate preferences, during the summer season, of the lake's macrozoobenthos.

The spatial or temporal structures of ecosystems form a major element in most ecological theories (Legendre \& Fortin, 1989) and patchy aggregates or gradients are the rule in each species or community rather than uniform or ran- dom distributions. With our data, we sought to determine whether species and communities from Lake Redó are effectively distributed in aggregates, with clear depth or substrate limits separating them, or whether they form a continuous and replacing gradient of species.

\section{SAMPLING SITE AND METHODS}

The main physiographic and physico-chemical characteristics of the glacial Lake Redó are summarized in Table 1. The ecology of the lake is quite well known, following the research undertaken by Catalán and co-workers (e.g. Catalán, 1988; Catalán \& Camarero, 1991). Previous data about the upper littoral and profundal benthic community and their relationship with acidification can also be found in Rieradevall et al. (1998) and Rieradevall \& Prat (1999).

The sampling design consisted in the collection of samples at 2-m intervals along a bathymetric transect in the SE area of the lake (Fig.1), from the upper littoral zone to $20 \mathrm{~m}$, in summer (July 15, 1997). Stones and soft sediment samples were taken independently at each depth. Three stones were collected by SCUBA divers from the stony bottom and placed in separate plastic bags with zip fasteners and were considered as replicates (Särkkä, 1983). Three cores (5.6 $\mathrm{cm}$ or $2.5 \mathrm{~cm}$ in diameter depending) were also taken, by hand, from the soft bottom on the area between the stones or blocks. It was not possible to take suitable sediment samples at depths shallower than 8-m due to the lack of sediment and the abundance of stones covering the bottom of the lake. Three replicate samples were collected with an Ekman grab $\left(225 \mathrm{~cm}^{2}\right.$ base area) of the profundal area of the lake (i.e. at $22-25 \mathrm{~m}$ and at $63 \mathrm{~m}$ ) at the two sites which had low slopes and, therefore, higher sediment accumulation.

A total of 30 stones and 24 sediment samples were taken. A record was kept of the macroscopic cover on the stones (i.e. the presence of mosses, cyanophyte mats and inorganic material mixed with detritus particles). Surface area suitable for colonization by invertebrates was 


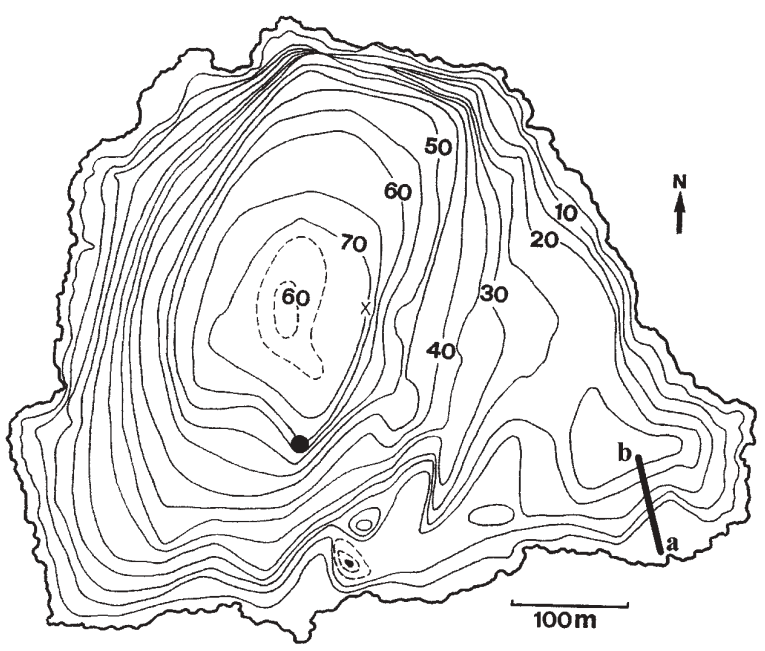

Figure 1. Bathymetric map of Lake Redó showing the transect (a, b) along which samples were taken and the sampling point at $63 \mathrm{~m}$ (black dot). Mapa batimétrico del lago Redó en el que se muestra el transecto $(a, b)$ en el que se tomaron muestras y la estación de muestreo a 63 m de profundidad (círculo negro).

estimated for each stone by wrapping with aluminium foil, and using a weight/area ratio drawn for the aluminium. In the laboratory, the stones were washed several times and carefully brushed to detach all covering material. The collected material was filtered through a $250 \mu \mathrm{m}$ mesh, sorted under a stereoscope and animals preserved in $70 \%$ ethanol in vials. Grab samples were filtered in the field using a net of $250 \mu \mathrm{m}$ mesh size, while core samples were transported to the laboratory where the filtration was performed. Preservation, sorting and preparation were similar to those used with the stone samples. After two days, the unprocessed samples were fixed with formalin awaiting study. In all cases, chironomid larvae and pupae were conveniently mounted with Euparal in slides for identification at species level.

To test statistically for the presence of spatial structures in the distribution of the community with depth we performed a Mantel autocorrelogram analysis. A global significance test was carried out and the Bonferroni method used for correcting for multiple tests. When the autocorrelogram was positive, the spatial structure was analysed using a multivariate method of clustering with a spatial contiguity constraint (Legendre \& Vaudor, 1991).

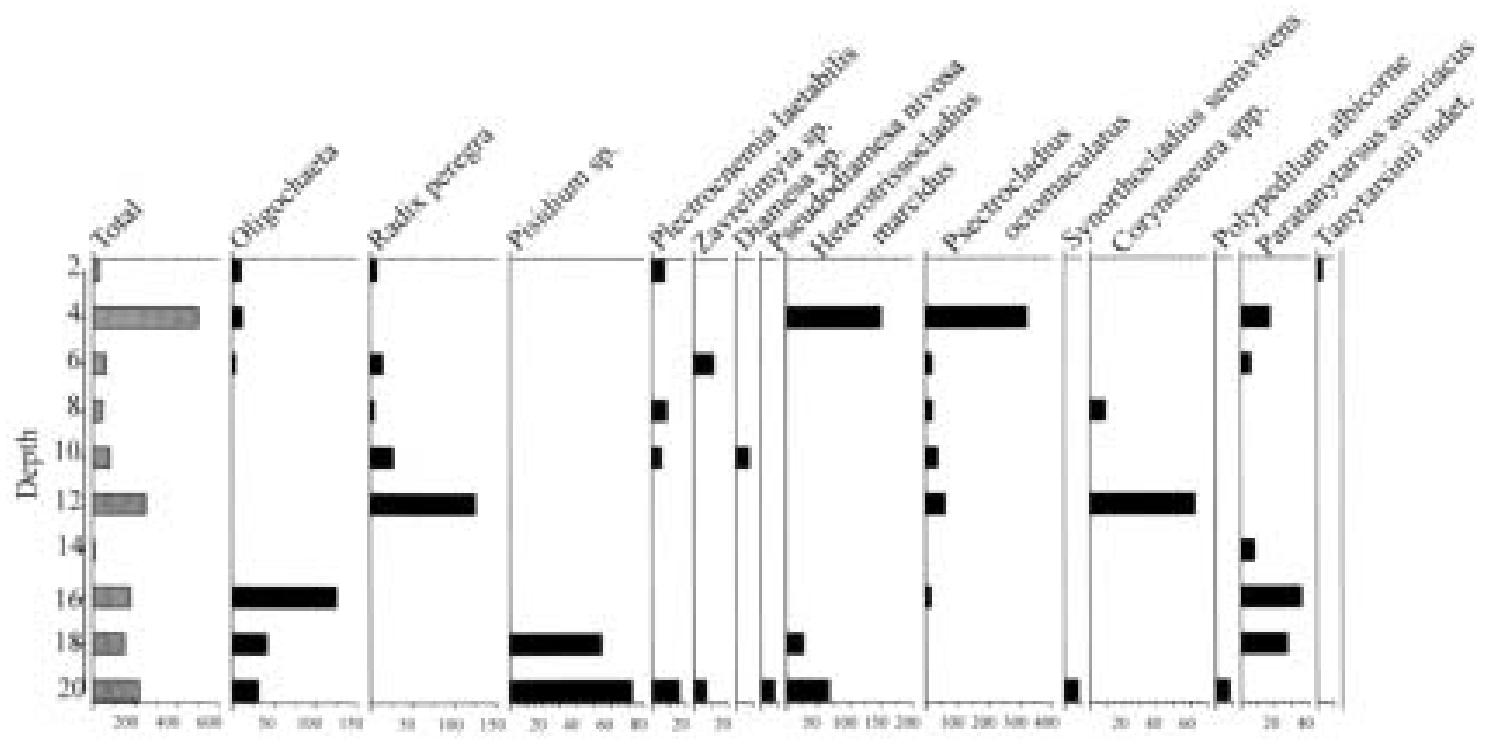

Figure 2. Densities (ind $\mathrm{m}^{-2}$ ) of benthic macroinvertebrate taxa on stones at each sampled depth. Densidades (ind $m^{-2}$ ) de los taxones de macroinvertebrados sobre sustratos de piedras en cada profundidad muestreada. 
Tabla 1. Main physiographic and water physico-chemical characteristics of Lake Redó. Características fisiográficas del lago Redó y fisico-químicas del agua.

\begin{tabular}{ll}
\hline Latitude/Longitude & $42^{\circ} 38^{\prime} \mathrm{N} 0^{\circ} 46^{\prime} \mathrm{E}$ \\
Altitude (m a.s.1.) & $2240 \mathrm{~m}$ \\
Annual rainfall & $1300 \mathrm{~mm}$ \\
Catchment geology & granodiorites \\
Lake area & $24 \mathrm{ha}$ \\
Maximum depth & $73 \mathrm{~m}$ \\
Mean depth & $32 \mathrm{~m}$ \\
Maximum depth sampled & $63 \mathrm{~m}$ \\
Mean slope & $20 \%$ \\
pH & 6.32 \\
Conductivity & $12.1 \mu \mathrm{S} \mathrm{cm}{ }^{-1}$ \\
Tot-P & $0.16 \mu \mathrm{M}$ \\
Fishes & Salmo trutta \\
\hline
\end{tabular}

\section{RESULTS}

Fourteen taxa were identified in stone samples, 10 of which were chironomids. Their densities and depth distribution are shown in figure 2 . Sediment communities appeared to be less diverse than those living on stones, with 8 taxa (6 chironomids) (Fig. 3 and Table 2).

Some of the taxa were specific to stone substrates, including the gasteropod Radix peregra, the polycentropodid trichoptera Plectrocnemia laetabilis and some chironomid species (e.g. Synorthocladius semivirens, Psectrocladius octomaculatus, Polypedilum albicorne and Paratanytarsus austriacus) (Table 2). The two most abundant species on stones were the chironomids Psectrocladius octomaculatus, with maximum densities of around 350 ind $\mathrm{m}^{-2}$, and Heterotrissocladius marcidus, with densities reaching 150 ind $\mathrm{m}^{-2}$ (Fig. 2). The latter species was present also in soft sediments where it reached its maximum densities (2000 ind $\mathrm{m}^{-2}$; Fig. 3). In contrast, a marked preference for the soft substrate was observed in other chironomid species such as Micropsectra radialis and Pseudodiamesa nivosa, both with densities around 150 ind $\mathrm{m}^{-2}$ (Fig. 3).

Mantel's analysis of autocorrelation for the macroinvertebrate community in the stone samples was globally significant, showing the presence of a definite spatial pattern (Fig. 4). Clustering grouping techniques applied with a contiguity constriction identified three groups of samples at a connectedness level of 0.5 (probability level 0.2 ): (i) $2-4 \mathrm{~m}$ (the littoral zone); (ii) 6 to $14 \mathrm{~m}$ (the sublittoral) and (iii) beyond $14 \mathrm{~m}$ (the profundal zone). This grouping agrees with the Mantel correlogram shown in figure 4. Therefore, we can conclude that communities are distributed in depth aggregates, rather than following a continuous gradient. This grouping is consistent with the energy inputs and internal dynamics of this lake. Thus, the thermal gradient in the sublittoral and the littoral to a depth of 14 $\mathrm{m}$, varies during the year from 4 to $14{ }^{\circ} \mathrm{C}$, while in the profundal it remains below $5^{\circ} \mathrm{C}$. The depth of $14 \mathrm{~m}$ coincides with the lower part of the ther-

Tabla 2. Mean abundance (ind $\mathrm{m}^{-2}$ ) and relative proportion of the different taxonomic orders of macroinvertebrates in stony and soft bottoms along a bathymetric transect in Lake Redó (July 15, 1997). Abundancia promedio (ind $\mathrm{m}^{-2}$ ) y proporción relativa de los órdenes de macroinvertebrados sobre sustratos rocosos y sedimentos a lo largo de un transecto batimétrico en el lago Redó (15 de Julio de 1997).

\begin{tabular}{|c|c|c|c|c|}
\hline & \multicolumn{2}{|c|}{ stony bottoms } & \multicolumn{2}{|c|}{ soft bottoms } \\
\hline & ind $\mathbf{m}^{-2}$ & $\%$ & ind $\mathbf{m}^{-2}$ & $\%$ \\
\hline Oligochaeta & 22.62 & 14.62 & 914 & 38.36 \\
\hline Gastropoda & 17.98 & 11.62 & 0 & 0 \\
\hline Sphaeriidae & 12.75 & 8.24 & 23.7 & 1.00 \\
\hline Trichoptera & 3.83 & 2.48 & 0 & 0 \\
\hline Chironomidae & 97.5 & 63.04 & 1445 & 60.65 \\
\hline Total Nb. taxa & 14 & & 8 & \\
\hline Nb. Chironomidae species & 10 & & 6 & \\
\hline
\end{tabular}




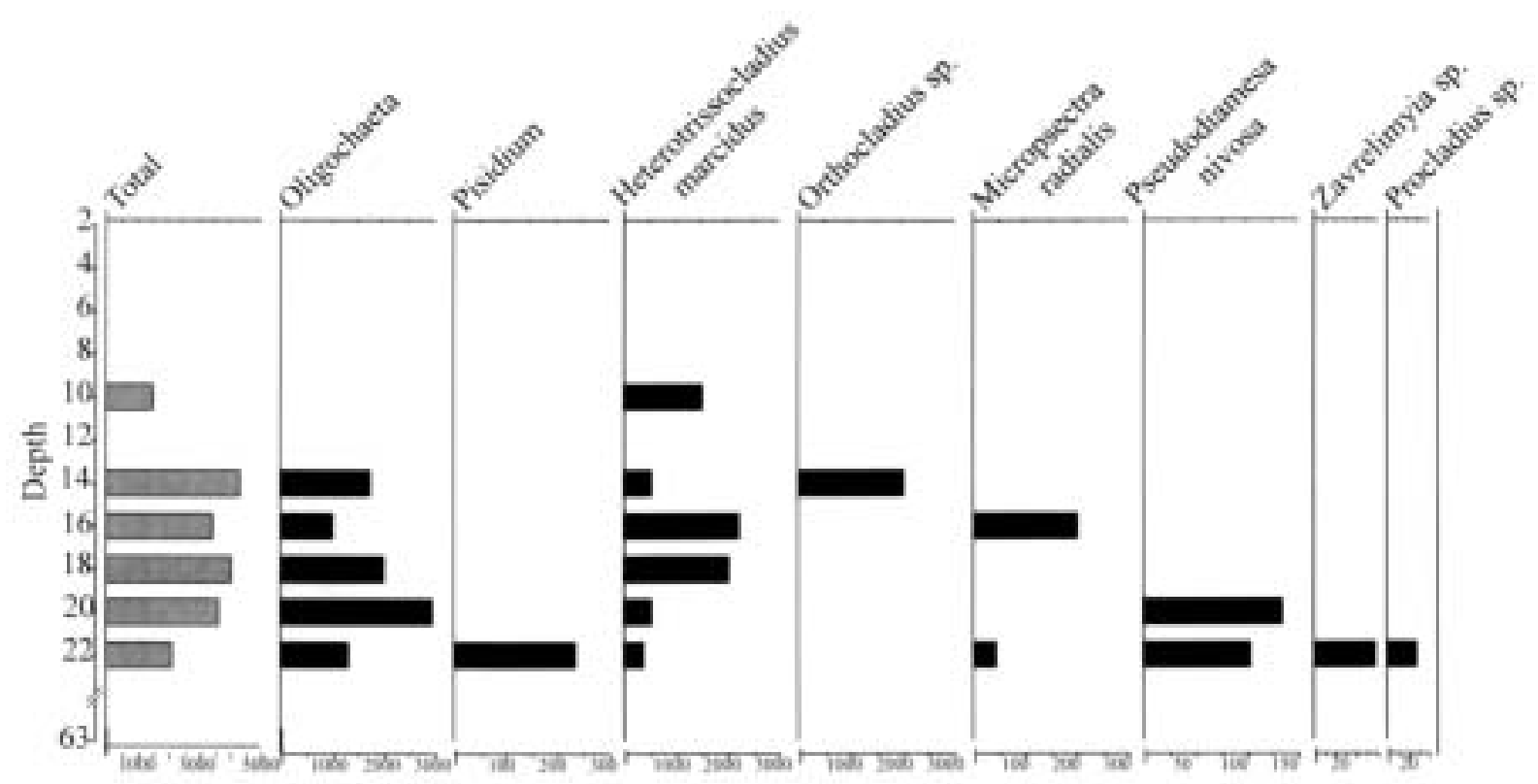

Figure 3. Densities (ind $\mathrm{m}^{2}$ ) of benthic macroinvertebrate taxa in sediment samples at each depth. Densidades (ind $m \mathbf{-}^{2}$ ) de los táxones de macroinvertebrados presentes en los sedimentos en cada profundidad muestreada.

mocline in summer in Lake Redó (Catalán, 1988). There was also a change in the slope at this depth in the transect area studied, which enhances the significance of the temperature discontinuity. At this depth the light environment is poor, with light levels less than $10 \%$ of incident light at the water surface (Catalán, op.cit).

The macroscopic cover of stones was constituted by mosses, two kinds of cyanobacteria (Nostoc and Stigonema) and inorganic particles mixed with fine detritus. The analysis of the distribution of this cover (Fig. 5) shows that, while Nostoc and Stigonema were found down to the "critical" depth of 12-14 m, mosses were found in deeper areas. Indeed, mosses were found down to a depth of $40 \mathrm{~m}$ and at even greater depths in grab samples. The amount of inorganic and detritic particles also increased substantially with depth, even on the stones, and were the main substrate occurring at $18-20 \mathrm{~m}$. This would increase the presence and explain the higher abundance of species more typical of soft substrates such as Pisidium (Fig. 5).
The autocorrelation analysis of sediment samples proved not to be significant, indicating a homogeneous environment and, therefore, that the densities of the macroinvertebrate community at depths ranging from 8 to $22 \mathrm{~m}$ were not significantly different in this kind of substrate. Nevertheless, the deepest community (i.e. at 63 $\mathrm{m})$ presented very low densities and diversity in July, and only a few oligochaetes and some chironomids from the abundant species Heterotrissocladius marcidus were present in samples.

\section{DISCUSSION}

Our data show that diversity decreases with depth and is greater on hard than on soft substrates. These results coincide with those reported in most of the lakes studied (Brinkhurst, 1974). Lake Redó has a low diversity compared with other oligotrophic (e.g. Särkkä, 1983) and cold stenothermic large lakes (e.g. Lake Michigan, Winnell \& White, 1986; Lake Léman, Crozet, 


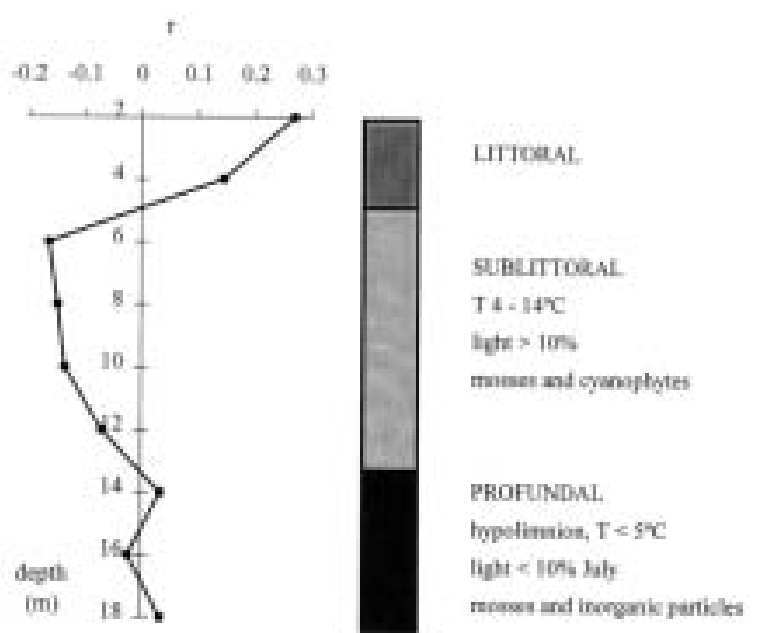

Figure 4. Mantel autocorrelogram $(\mathrm{r}=$ standardized Mantel stadistic) of stone samples (left) and the clustering of sampling stations, constrained by contiguity analysis (value of connectedness $=0.5$; probability 0.2) (right). Autocorrelograma de Mantel ( $r=$ estadistico estandarizado de Mantel) de las muestras de piedras (izquierda) $y$ agrupación de las estaciones de muestreo (conectancia $=0,5$; probabilidad 0,2) (derecha).

1984; Lake Königsee, Siebeck, 1991). Its biodiversity, however, is comparable to that found in remote high mountain lakes (Whatne et al. 1995; Bitusík \& Koppová, 1997). The absence of macrophytes in the littoral zone may explain the low diversity found in Lake Redó, particularly when comparing it with other richer, Pyrenean lakes (Laville, 1972).

Substrate preferences are those typically described in other lakes, with gastropoda and trichoptera found only on hard substrates and bivalvia on soft substrates. Radix peregra have also been found dominating the littoral zone, in areas from 0 to $10 \mathrm{~m}$ depth, in the subarctic Lake Thyngvallavatn, especially in areas where silt was scarce, on/and between the stones (Lindegaard, 1992). The presence of Pisidium at depths below $18 \mathrm{~m}$ in Lake Redó and its increasing density with depth are consistent with their known preference for fine sediments (Lindegaard, op.cit.). Among the chironomids, the presence of Psectrocladius octomaculatus, Paratanytarsus austriacus and Corynoneura sp.,

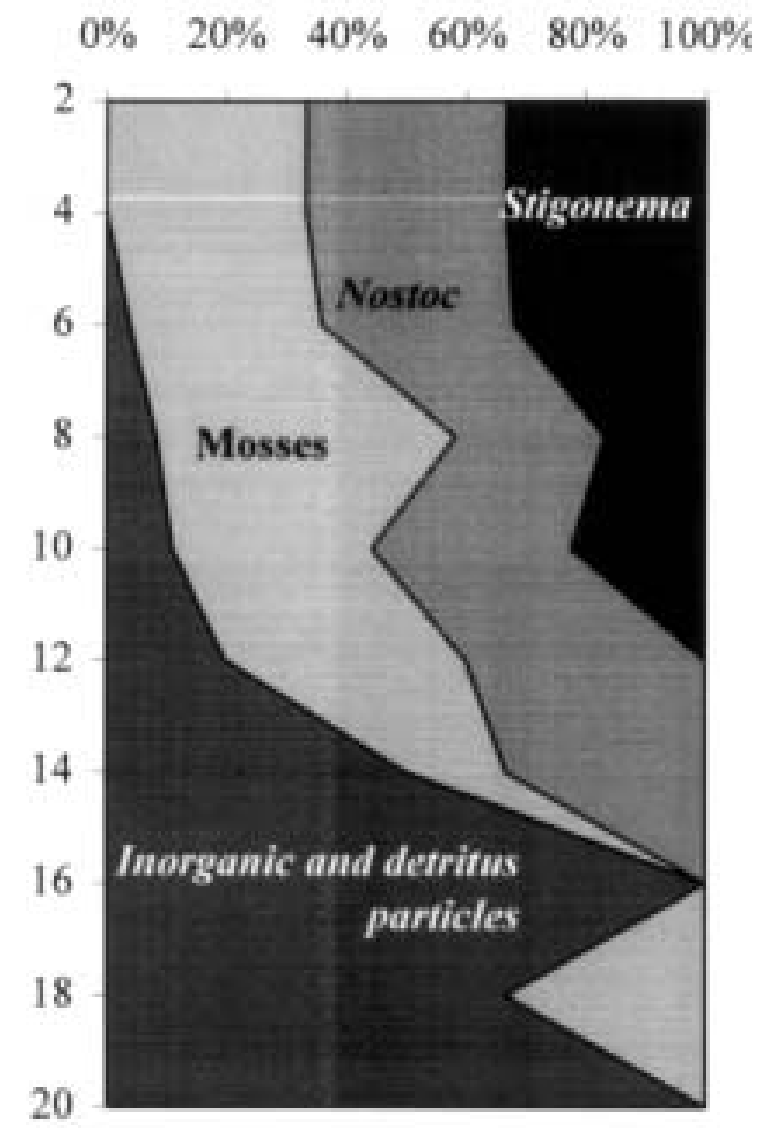

\section{depth (m)}

Figure 5. Relative abundance (\%) of the components of the macroscopic cover of stones. Abundancia relativa (\%) de los componentes de la cubierta macroscópica de las piedras.

on stony bottoms down to depths of $14 \mathrm{~m}$, is in accordance with findings reported elsewhere (e.g.: Särkkä, 1983; Wisseman et al. 1993; Whiteside \& Lindegaard, 1982). Nevertheless, while $P$. austriacus is widespread in high altitude and high latitude regions, Psectrocladius octomaculatus, found in Lake Redó, seems to be a sibling species of other Psectrocladius species present and characteristic of oligotrophic and cold northern lakes (such as P. edwardsi in Thingvallavatn or P. limbatellus and P. sordidellus in Norwegian lakes; Fjellheim et al., 1997). On the other hand, the dominant chironomids in 
soft substrates of Lake Redó were Micropsectra radialis and Pseudodiamesa nivosa, coinciding with findings in other high mountain lakes. The most abundant chironomid was Heterotrissocladius marcidus. This species showed no preference for substrate or depth in our lake, as described for other species of the same genera in other lakes (Winnell \& White, 1984; Lindegaard 1992). The abundances of individuals per square meter on stones in Lake Redó were very low compared with data reported elsewhere (Lindegaard, 1992).

Our results should be useful in aiding the palaoelimnological interpretation of subfossil records. With the autoecological information obtained in this study, the abundance of the different species in the core samples can be interpreted in terms of substrate and depth characteristics of the lake during the time of sediment deposition. The absence of plant-associated macroinvertebrate species in Lake Redó, abundant in other Pyrenean lakes (Laville, 1972) can also serve as an indicator of characteristics of the lake in the past. With these and other data about the autoecology of recent macrozoobenthic fauna we can provide better explanations of past changes recorded as subfossil remains in the cores taken from the lake.

\section{ACKNOWLEDGEMENTS}

This paper would have never been published without the enthusiasm and dedication shown by divers Jaume Piera and David Díaz, who sampled stones and cores in very cold waters. Financial support came from the EU project MOLAR (Mountain Lake Research) ENV4-CT95-0007.

\section{REFERENCES}

BITUSÍK, P. \& K. KOPPOVÁ. 1997. Macrozoobenthos of the glacial lakes in the Low Tatras (West Carpathians): Aquatic insects. Biologia, Bratislava, 52:227-232.

BRINKHURST, R. O. 1974. The benthos of lakes. McMillan Press Ltd. London. 190 pp.
CATALÁN, J. 1988. Physical properties of the environment relevant to the pelagic ecosystem of a deep high-mountain lake (Estany Redó, Central Pyrenees). Oecologia Aquatica, 9: 89-123.

CATALÁN, J. \& L. CAMARERO. 1991. Ergoclines and biological processes in high mountain lakes: Similarities between summer stratification and the ice-forming periods in Lake Redó (Pyrenees). Verh. Internat. Verein. Limnol., 24: 1011-1015.

CROZET, B. 1983. Evolution de la macrofaune benthique littorale du Lac Léman de 1837 à 1983. Revue suisse Zool., 91 (4): 879-894.

FJELLHEIM, A., M. RIERADEVALL, G. RADDUM \& O. SCHNELL. 1997. AL:PE 2 report for the period January 1993-June 1995. 3. Contemporary biology: 3.1. Invertebrates. Unpublished Report for the EU project AL:PE 2 (Acidification of Mountain lakes: Palaeolimnology and Ecology. Remote Mountain Lakes as Indicators of Air Pollution and Climate Change). 56 pp.

JÓNASSON, P. M. 1978. Zoobenthos of lakes. Verh. Internat. Verein. Limnol., 20: 13-37.

LAVILLE, H. 1972. Recherches écologiques sur les Chironomides (Diptera) des lacs de montagne. Thèse. Univ. Paul Sabatier. Toulouse. France. 413 pp.

LEGENDRE, P. \& M. J. FORTIN. 1989. Spatial pattern and ecological analysis. Vegetatio, 80: 107138.

LEGENDRE, P. \& A. VAUDOR. 1991. The $R$ Package: multidimensional analysis, spatial analysis. Département de Sciences Biologiques, Université de Montréal, iv $+142 \mathrm{p}$.

LINDEGAARD, C. 1992. Zoobenthos ecology of Thingvallavatn: vertical distribution, abundance, population dynamics and production. Oikos 64: 257-304.

RIERADEVALL, M., M. JIMÉNEZ \& N. PRAT. 1998. The zoobenthos of six remote high mountain lakes in Spain and Portugal. Verh. Internat. Verein. Limnol., 26: 2132-2136.

RIERADEVALL, M. \& N. PRAT. (1999). Chironomidae from high mountain lakes in Spain and Portugal. In: Late 20 th Century Research on Chironomidae: An Anthology from the 13 th International Symposium on Chironomidae. Hotfrichter, O. (ed.): 605-613. Shaker Verlag, Aachen.

SÄRKKÄ, J. 1983. A quantitative ecological investigation of the littoral zoobenthos of an oligotrophic Finnish lake. Ann. Zool. Fennici., 20: 157-178. 
SIEBECK, O. 1989. Königsee- an oligotrophic lake. In: Limnology in the Federal Republic of Germany. W. Lampert \& O. Rothhaupt (eds.): 32-36. Plön.

UUTALA, A. J. 1981. Composition and secondary production of the chironomid (Diptera) communities in two lakes in the Adirondack mountain region. In: Effect of Acidic Precipitation on Benthos. R. Singer (ed): 139-154. North American Benthological Society. Hamilton. New York.

WATHNE, B. M., S. T. PATRICK, D. MONTEITH \& H. BARTH 1995. AL:PE 1 Report for the period April 1991-April 1993. Ecosystems Research Report 9. Report EUR 16129 EN European Commission, Luxembourg. 296 pp.
WHITESIDE, M. C. \& C. LINDEGAARD. 1982. Summer distribution of Zoobenthos in Grane Langsø, Denmark. Freshwat. Invertebr. Biol., 1(1): 2-16.

WINNELL, M. H. \& D. S. WHITE. 1986. The distribution of Heterotrissocladius oliveri Saether (Diptera: Chironomidae) in Lake Michigan. Hydrobiologia, 131: 205-215.

WISSEMAN, R.W., N. H. ANDERSON, M. BUKTENICA \& G. L. LARSON. 1993. Benthic macroinvertebrates of Crater Lake and Caldera Springs. In: Crater Lake Limnological studies. Final report. G. L. Larson, C.D. McIntyre \& R.W. Jacobs (eds.): 619-701. Cooperative Park Studies Unit, College of Forestry, Oregon State University, Cornwallis, Oregon. 